\title{
Yeast extract with blood plasma in diets for piglets from 21 to 35 days of age
}

\author{
Cinthia Maria Carlos Pereira ${ }^{1}$, Juarez Lopes Donzele ${ }^{2}$, Francisco Carlos de Oliveira Silva ${ }^{3}$, \\ Rita Flávia Miranda de Oliveira ${ }^{2}$, Charles Kiefer ${ }^{4}$, Aloízio Soares Ferreira ${ }^{2}$, Melissa Izabel \\ Hannas ${ }^{2}$, Paulo César Brustolini²
}

\author{
${ }^{1}$ Masters Program, DZO/UFV. \\ ${ }^{2}$ DZO/UFV. \\ ${ }^{3}$ EPAMIG \\ ${ }^{4}$ DZO/UFMS.
}

\begin{abstract}
The objective of this study was to evaluate the inclusion of yeast extract as a partial replacemer of blood plasma in piglet diets and its effect on the performance and intestinal morphometry of pigs weaned at 21 days of age. One hundred and twenty animals were randomized into blocks, with five diets $(4.0 \%$ blood plasma; $2.0 \%$ blood plasma with 0.0 ; $1.0 ; 2.0$ or $3.0 \%$ yeast extract), six replicates and four pigs per experimental unit. At 35 days of age, one pig per experimental unit was slaughtered in order to evaluate duodenal and jejunal morphometry. The levels of yeast extract had a quadratic impact on daily feed intake and final weight, which increased up to the estimated level of $1.91 \%$. Daily weight gain and feed conversion rate were not affected. A comparison between diets containing different levels of yeast extract and the basal diet showed that the diets containing $2.0 \%$ and $1.0 \%$ yeast extract provided the highest final weight and the worst feed conversion rate, respectively. Duodenal villus height and crypt depth were quadratically affected by yeast extract levels and the best results were achieved with the estimated levels of 1.64 and $1.16 \%$, respectively. The levels of yeast extract provided a linear increase in the duodenal villus:crypt ratio, but did not change the morphometric variables of the jejunum. No difference was found in the morphometric variables of the duodenum and jejunum when diets containing different levels of yeast extract were compared with the basal diet. The results suggest that the inclusion of $1.91 \%$ yeast extract allows for a partial replacement for plasma in the diet, decreasing plasma inclusion from 4.0 to $2.0 \%$.
\end{abstract}

Key Words: intestinal mucosa, nucleotides, performance, swine

\section{Introduction}

Early weaning has been used in swine production in order to shorten the exposure time of piglets to the pathogens of their sows and increase the number of finished animals/ sow/year. However, early-weaned piglets fail to achieve digestive and immune maturity, compromising performance (Coffey \& Cromwell, 2001). Therefore, the weaning period has challenged nutritionists, who have sought alternative feeding sources to minimize performance issues (particularly feed intake) that affect animals during this phase. These feed sources include, preferably, highly digestible and palatable feeds such as spray-dried blood plasma.

Spray-dried blood plasma has been used not only because it is a good source of immunoglobulins and animal-based proteins of high biologic value, but also for the presence of glutamic acid, which increases feed intake thanks to its palatable properties (Lawrence et al., 2004).

Yeast extract from the inner cell wall of a specific strain of Saccharomyces cerevisae 1026 can be a functional source of nutrients, since it is rich in peptides, inositol (a potential growth promotant), glutamic acid (associated with palatability) and nucleotides (Costa, 2006).

Nucleotides are involved in several biochemical processes that are essential to the body functions (Lehninger et al., 2002) and play a key role in the growth and development of intestinal cells and the immune system. They can be considered an essential nutrient for animals under fast growth conditions and stress (such as postweaning pigs). Therefore, yeast extract should be included in post-weaning diets due to its essential functions and for its synergistic effect on the blood plasma.

The combined use of blood plasma and yeast extract may attenuate the negative impact on piglet performance during the very stressful post-weaning phase, from 21 to 35 days of age. In that sense, the objective of this study was to evaluate the addition of yeast extract to partially replace blood plasma and to verify the effects on performance and intestinal morphometry of piglets from 21 to 35 days of age. 


\section{Material and Methods}

The experiment was conducted at the Swine Sector of the Departamento de Zootecnia of Universidade Federal de Viçosa, in Viçosa, Minas Gerais state, Brazil. The study included 120 piglets, barrows and gilts, from 21 (weaning) to 35 days of age (initial weight between $6.12 \pm 0.35 \mathrm{~kg}$ ). The animals were randomized into blocks, with five treatments (4.0\% blood plasma (BP); $2.0 \%$ blood plasma with $0.0 ; 1.0$; 2.0 and $3.0 \%$ yeast extract (YE)), six replicates and four animals per experimental unit. The blocks were based on the weight of animals at weaning.

The experimental diets (Tables 1 and 2) had the same quantity of energy and amino acids, formulated in order to meet the nutritional requirements of 21 to 35 -day old piglets, according to Rostagno et al. (2005). The digestible lysine-to-other essential amino acid ratios were achieved based on the ideal protein standard established by Rostagno et al. (2005).
The animals were housed in suspended pens with slatted floor, semi-automated feeders and nipple drinkers, in masonry barns with concrete floor, wood ceiling and ceramic tiles. A thermometer was used to record daily temperature variations inside the room, at $4 \mathrm{pm}$, throughout the experimental period. Low and high temperatures were $24.7 \pm 0.62$ and $28.1 \pm 0.90^{\circ} \mathrm{C}$, respectively.

The animals were fed the experimental diets and water ad libitum throughout the experiment. In order to assess performance variables, the weight of animals was recorded at the beginning and end of each experimental phase in order to determine daily weight gain (DWG). Feed leftovers on the floor were collected daily and added to leftovers in the feed bunk at the end of the experimental period, in order to determine daily feed intake (DFI) and feed conversion rate (FCR).

At 35 days of age, one animal per experimental unit (the one whose weight was closest to the mean of the pen) was slaughtered. After the intestine was flushed, samples of

Table 1 - Percentage and nutritional compositions of experimental diets fed to 21 to 35 day-old piglets

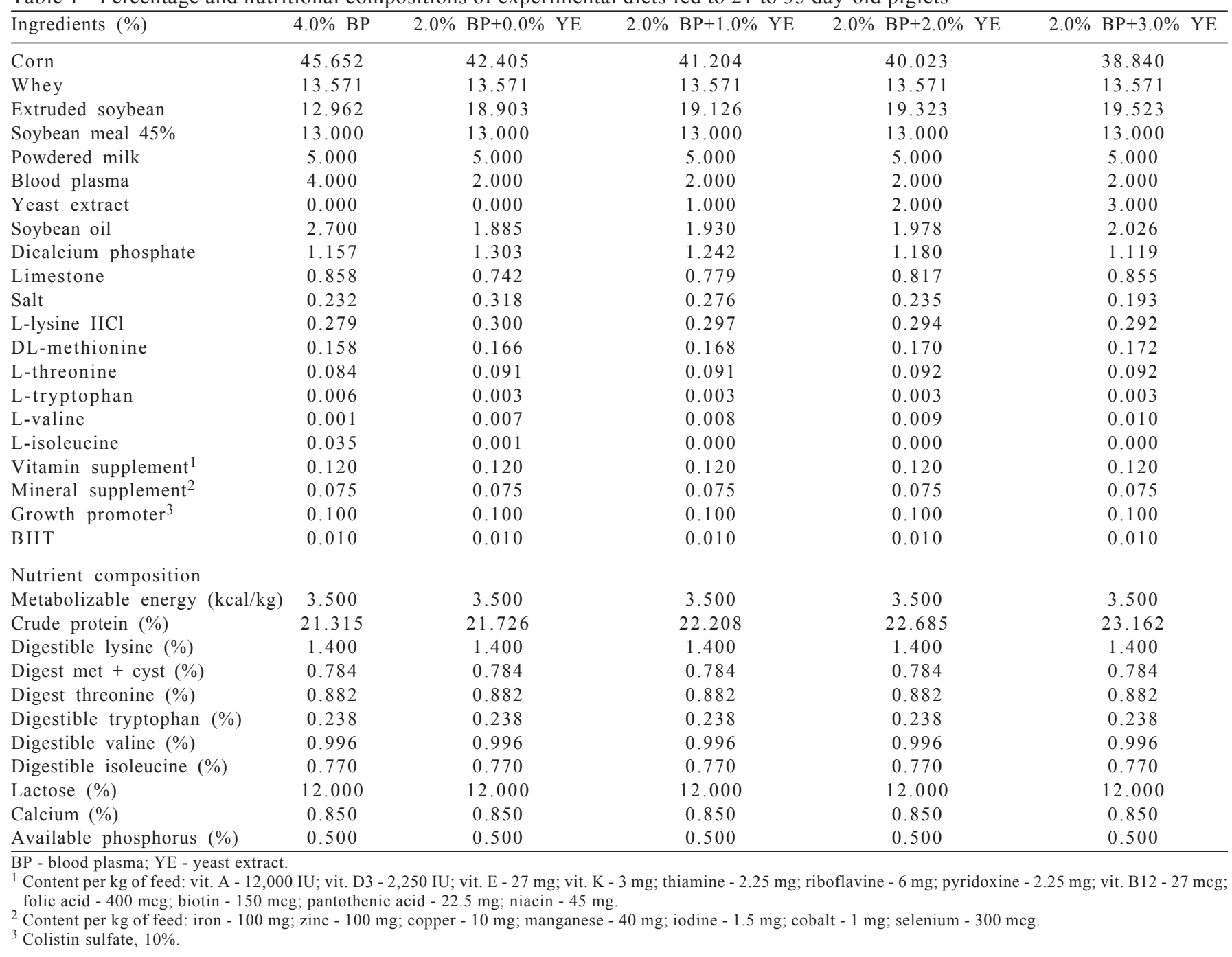


Table 2 - Nutrient composition of blood plasma AP 920 and yeast extract NuPro ${ }^{\circledR}$

\begin{tabular}{lcc}
\hline Nutrients & $\begin{array}{c}\text { Blood plasma } \\
\text { AP } 920^{1}\end{array}$ & $\begin{array}{c}\text { Yeast extract } \\
\mathrm{NuPr}^{2 \circledR}\end{array}$ \\
\hline Metabolizable energy (kcal/kg) & 3906 & 3314 \\
Crude protein (\%) & 78.0 & 43.70 \\
Calcium (\%) & 0.15 & 0.02 \\
Available phosphorus (\%) & 1.30 & 1.20 \\
Sodium (\%) & 2.20 & 0.27 \\
Potassium (\%) & 0.30 & 1.15 \\
Lysine (\%) & 6.80 & 2.65 \\
Methionine (\%) & 0.70 & 0.63 \\
Threonine (\%) & 4.80 & 1.60 \\
Tryptophan (\%) & 1.40 & 0.34 \\
Valine (\%) & 5.30 & 2.15 \\
Isoleucine (\%) & 2.90 & 1.64 \\
Glutamic acid (\%) & 11.70 & 4.98 \\
Nucleic acid (\%) & - & $5.20-6.60$ \\
Inositol (mg/kg) & - & 5.83 \\
\hline 1 APC An LGl Company. & & \\
2 Alltech. & &
\end{tabular}

approximately 2 centimeters were collected, accounting for 4 and $50 \%$ of the small intestine (duodenum and jejunum, respectively). The samples were sent to the Laboratório de Histologia of the Departamento de Medicina Veterinária of Universidade Federal de Viçosa for histological sections and slide preparations for subsequent examination. The histological sections were flushed in saline solution, fixed in BOUIN for 24 hours, dehydrated in ethyl alcohol, diaphanized in xylol and added to paraffin. Each slide had two $5 \mu \mathrm{m}$ thick sections. The slides were added to a xylol solution for a second time, in order to remove excess paraffin, and hydrated again. Hematoxylin and eosin (H\&E) was the stain used. Once stained, the slides were dehydrated again. In order to read the slides, an optical microscope (Olympus bx50,40x magnification) was coupled to an image analyzer (Image-Pro Plus 1.3.2). Thirty villus heights and 30 crypt depths were selected and measured by slide. The villus:crypt ratio was then calculated.

Statistical analyses of performance parameters and morphometry of the intestinal mucosa were carried out with SAEG (Sistema de Análises Estatísticas e Genéticas, version 8.0). The results were submitted to analysis of variance. The mean values of diets containing different levels of yeast extract were submitted to regression analysis. In addition, the Dunnett test (Sampaio, 1998) was used to compare the mean values of each yeast extract containing plasma with the average value of the control diet. A $10 \%$ significance level was used in all the tests performed.

\section{Results and Discussion}

The levels of yeast extract affected $(\mathrm{P}<0.06)$ the final weight of the piglets (Table 3 ), which increased quadratically up to the estimated level of $1.91 \%$ in the diet (Figure 1). A comparison of the final weight of the animals fed the control diet with the final weight of those fed the other diets showed that while the piglets fed the $2.0 \%$ plasma diet with no addition of yeast extract had a non-significant decrease of $3.95 \%$ in the absolute value of the final weight $(9.49 \times 9.88 \mathrm{~kg})$, the final weight of animals fed the diet containing $2.0 \%$ plasma $+2.0 \%$ yeast extract was significantly higher $(10.38 \times 9.88 \mathrm{~kg})$.

The addition of $2.0 \%$ yeast extract decreased blood plasma levels in the diet by $50 \%$, improving the final weight of 35-day-old piglets. Considering the positive correlation between piglet weight in the early post-weaning period and the growth rate in subsequent phases up to slaughter (Klindt, 2003), one can assume that the combined use of $2.0 \%$ plasma and $2.0 \%$ yeast extract in the diet may be a feasible strategy in pig nutrition in order to lower the slaughter age of these animals. Carlson et al. (2005) demonstrated that the addition of yeast extract to the diet of nursery piglets improved their performance in subsequent phases, allowing them to reach the slaughter weight faster.

The levels of yeast extract affected $(\mathrm{P}<0.09)$ daily feed intake. There was a quadratic response up to the estimated level of $1.91 \%$ (Figure 2). This result was similar to the findings of Maribo \& Spring (2003) and Carlson et al. (2005), who showed a positive effect of yeast extract on the feed intake of post-weaning piglets.

Table 3 - Piglet performance by treatment (plasma and/or yeast extract from 21 to 35 days)

\begin{tabular}{|c|c|c|c|c|c|c|c|}
\hline \multirow[t]{2}{*}{ Parameters } & \multicolumn{7}{|c|}{ Treatments } \\
\hline & $4.0 \% \mathrm{BP}$ & $2.0 \% \mathrm{BP}+0.0 \% \mathrm{YE}$ & $2.0 \% \mathrm{BP}+1.0 \% \mathrm{YE}$ & $2.0 \% \mathrm{BP}+2.0 \% \mathrm{YE}$ & $2.0 \% \mathrm{BP}+3.0 \% \mathrm{YE}$ & Regression & $\mathrm{CV}(\%)$ \\
\hline W21 $(\mathrm{kg})$ & 6.10 & 6.07 & 6.18 & 6.18 & 6.08 & $\mathrm{~ns}$ & 1.91 \\
\hline W35 (kg) & $9.88 \mathrm{a}$ & $9.49 \mathrm{a}$ & $9.53 \mathrm{a}$ & $10.38 \mathrm{~b}$ & $9.70 \mathrm{a}$ & $Q^{2}$ & 4.97 \\
\hline DFI $(g)$ & 314 & 283 & 300 & 343 & 305 & $\mathrm{Q}^{1}$ & 10.40 \\
\hline DWG (g) & 270 & 244 & 240 & 300 & 259 & ns & 12.80 \\
\hline FCR & $1.16 \mathrm{a}$ & $1.16 \mathrm{a}$ & $1.25 \mathrm{~b}$ & $1.14 \mathrm{a}$ & $1.18 \mathrm{a}$ & ns & 7.18 \\
\hline
\end{tabular}

BP - blood plasma; YE - yeast extract; W21 - initial weight; W35 - final weight; DFI - daily feed intake; DWG - daily weight gain; FCR - feed conversion rate; CV coefficient of variation; Regression: Regression analysis of diets containing 0.0 to $3.0 \%$ yeast extract; ns - non-significant; a,b - mean values of each YE level followed by different letters in the same row are different from the control diet according to the Dunnett test; Q - quadratic effect.

${ }_{1}^{1} \mathrm{P}<0.06$.

${ }^{2} \mathrm{P}<0.09$. 


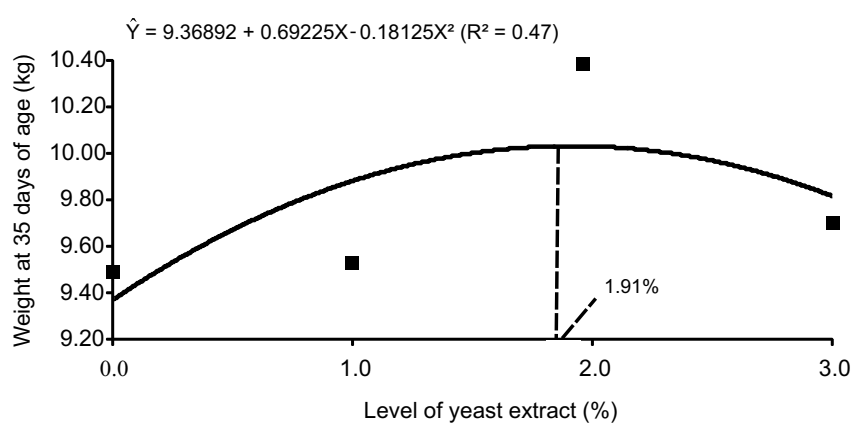

Figure 1 - Effect of yeast extract levels on weight at 35 days of age.



Figure 2 - Effect of yeast extract levels on daily feed intake.

On the other hand, Costa (2006) evaluated the inclusion of up to $6.0 \%$ yeast extract in the diet of piglets from 21 to 35 days of age and found no significant variation in feed intake.

The lack of consistent results among different papers may be related to factors such as environmental stress, immune challenge levels, and the complexity of the diets used in these studies. As reported by Coffey \& Cromwell (2001), the positive effects of functional feeds such as spray-dried blood plasma on pig performance are more dramatic when the animals are exposed to a higher level of immune challenge.

The higher feed intake shown in this study with the addition of up to $1.91 \%$ yeast extract to the animal diet may be associated with a potential protection that the yeast provides to the immune system and, consequently, the intestinal milieu.

The mechanism of action of yeast has not been fully understood yet. However, results from another study (Buts et al., 1990) show that yeasts can stimulate the gut-associated lymphoid tissue (GALT), increasing the production of immunoglobulin A, which acts on the intestinal lumen, decreasing the stimulation of the immune system and enhancing the appetite of the piglet.

Van der Peet-Schwering et al. (2007) supported these assumptions by showing that the use of yeast cultures in piglet diets lowered the levels of neutrophils in the plasma, whereas Shen et al. (2009) demonstrated that the addition of yeast culture in the diet decreases the circulating levels of cytokines (interferon $\alpha$ - IFN $\alpha$ ) in the first weeks of the post-weaning period. According to Abreu et al. (2010), the weanling piglet is exposed to several stress situations that activate the immune system and, hence the production of cytokines that eventually reduce the appetite.

No significant difference was found $(\mathrm{P}>0.10)$ in the daily feed intake of the animal when the piglets in the control $\operatorname{diet}(4.0 \%$ plasma) were compared with the animals fed the other diets. This result corroborates data by Rigueira (2009), who found no significant changes in the feed intake of piglets from 7 to 35 days of age when the diet with plasma inclusion $(4.0 \%)$ was compared with the diet combining plasma with yeast extract $(2.0 \% \mathrm{BP} ; 2.0 \% \mathrm{YE})$.

Although no significant difference $(\mathrm{P}>0.10)$ was found in the daily feed intake of different diets, the absolute value of the daily feed intake of piglets decreased $9.90 \%$ when plasma levels in the daily feed intake of piglets were reduced from $4.0 \%$ (basal diet) to $2.0 \%$ with no addition of yeast extract. Therefore, one can conclude that diets containing plasma levels lower than $4.0 \%$, with no addition of yeast can compromise piglet performance due to the negative impact on feed intake. Plasma is rich in glutamate (APC $\left.{ }^{\circledR}, 2007\right)$, which enhances palatability (Diehl, 2004) and protects the intestinal mucosa (Yu et al., 2002). Therefore, one can assume that the decrease in daily feed intake associated with plasma levels lower than $4.0 \%$ may be related to the decrease in the glutamate levels in the diet.

On the other hand, the combined use of $2.0 \%$ yeast extract and $2.0 \%$ plasma in the diet increased the daily feed intake of the piglets by $8.5 \%(343 \times 314 \mathrm{~g})$ compared with control animals. Although it was not significant $(\mathrm{P}>0.10)$ it was enough to improve $(\mathrm{P}<0.10)$ the final weight of the piglets at 35 days of age. These results point to a potential synergistic action between yeast extract and plasma.

The levels of yeast extract did not affect $(\mathrm{P}>0.10)$ the daily weight gain of piglets, whose average value corresponded to $261 \mathrm{~g}$. This result differs from those observed by Maribo \& Spring (2003), Carlson et al. (2005) and Costa (2006), who found a positive effect of yeast extract on growth rate in the first weeks after weaning.

One of the factors that may have contributed to the absence of significant changes in the daily weight gain of piglets fed different levels of yeast extract in the diet may be the low immune challenge to which the animals were exposed. This fact can be demonstrated by the high average growth rate of these animals (261 g). 
No significant difference was found in the daily weight gain of piglets fed the control diet compared with animals fed the other diets. This result is in line with data shown by Rigueira (2009), who found no variation in the daily weight gain of piglets when comparing a diet containing $4.0 \%$ plasma with another diet containing $2.0 \%$ plasma $+2.0 \%$ yeast extract. However, in absolute values, the daily weight gain of those piglets fed the diet containing $2.0 \%$ plasma + $2.0 \%$ yeast extract was $11 \%$ higher than the value observed in the animals fed the diet containing $4.0 \%$ plasma $(300 \mathrm{~g} \times$ $270 \mathrm{~g}$, respectively). This difference in growth rate may be explained by the higher daily feed intake of piglets fed the diet with 2.0\% yeast extract. According to Maribo \& Spring (2003) and Carlson et al. (2005), yeast extract acts as an appetite enhancer when added to animal feed.

The potential positive influence of nucleotides (present at high concentrations in yeast extract) on the gastrointestinal microflora, promoting the intestinal health and reducing the activation of the immune system in post-weaning piglets may be one of the reasons why yeast extract enhances the appetite of these animals (Mateo \& Stein, 2004).

The improved performance of the animals treated with $2.0 \%$ plasma $+2.0 \%$ yeast extract may be related to the supply of glutamate in the diet. A recent study by Moore et al. (2011), who assessed the effect of diets containing yeast extract and yeast extract components separately (inositol, glutamate and nucleotides) on pig performance during the post-weaning period, showed that the performance of animals fed the glutamate diet was similar to the performance of those fed yeast extract. Based on this result, one can assume that the benefit of yeast extract is associated with the presence of glutamate and, therefore, a decrease in the glutamate content in the diet can lower the feed intake, compromising pig performance.

The levels of yeast extract in the diet did not affect $(\mathrm{P}>0.10)$ the feed conversion rate of the piglets. In addition, van Heugten et al. (2003), Bontempo et al. (2006) and Shen et al. (2009) conducted several studies and could not show the impact of yeast extract in the feed efficiency of post-weaning pigs. In another research study evaluating the use of yeast in pig diets, van der Peet-Schwering et al. (2007) demonstrated that the positive effect of yeast on the feed conversion rate of the animals was only effective when compared with a control diet with no antibiotics.

A comparison of pigs treated with $4.0 \%$ plasma in the diet with animals fed diets containing $2.0 \%$ plasma at different levels of yeast extract showed that the combination of $2.0 \%$ plasma and $1.0 \%$ yeast extract in the diet of 21 to 35 -day old piglets had a negative impact $(\mathrm{P}<0.05)$ on the feed conversion rates of the piglets.

As to the intestinal morphometry analyses carried out with the pigs, the levels of yeast extract had an impact $(\mathrm{P}<0.07)$ on villus height and crypt depth of the duodenum (Table 4), which increased quadratically up to the estimated levels of 1.64 and $1.16 \%$, respectively (Figures 3 and 4). The levels of yeast extract also influenced $(\mathrm{P}<0.04)$ the duodenal villus:crypt ratio, providing a linear response.

The data on this experiment support the findings of Bontempo et al. (2006) and Shen et al. (2009), who also observed a positive effect of the addition of a yeast source to the diet on the intestinal morphometry of the piglets.

Based on the importance of nucleotides in the growth and development of the small intestine (Bueno et al., 1994) and the limited ability of intestinal mucosa cells to synthesize them (Leleiko et al., 1983) one can assume that high concentrations in yeast extract (Tibbets, 2002) can, in part, explain the benefits of this product on intestinal morphometry, as shown in this study.

To further support this assumption, Martinez-Puig et al. (2007) demonstrated the role of dietary nucleotide supplementation in order to prevent villus atrophy in weaning piglets. Recently, Sauer et al. (2011) reported that the inclusion of a nucleotide source in piglet diets may have a positive impact on intestinal morphometry, reducing the villus atrophy that typically occurs in the post-weaning period.

Table 4 - Morphometry of the duodenum and jejunum of 35-day old piglets as a function of treatments containing plasma (BP) and/ or yeast extract (YE)

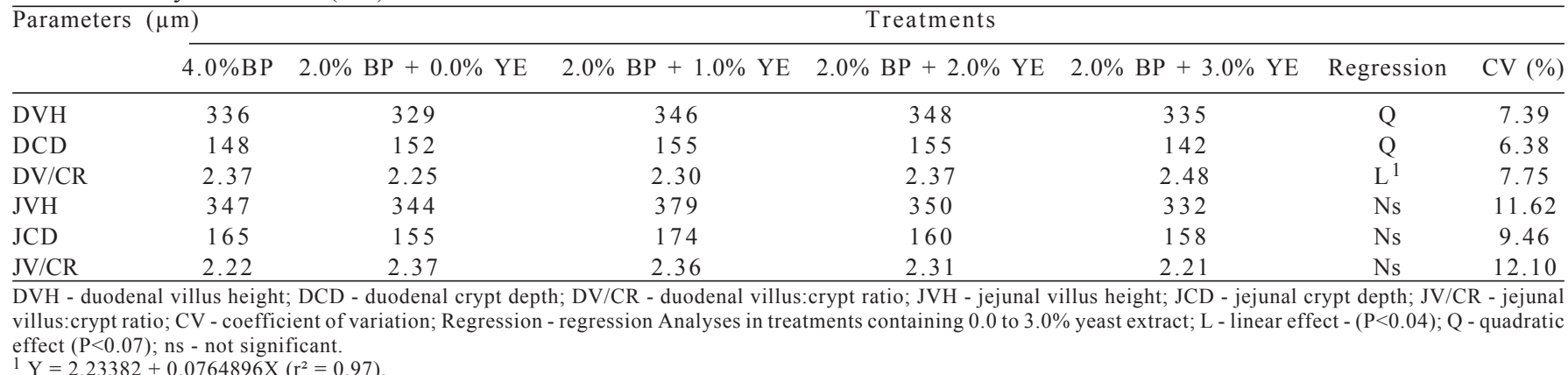




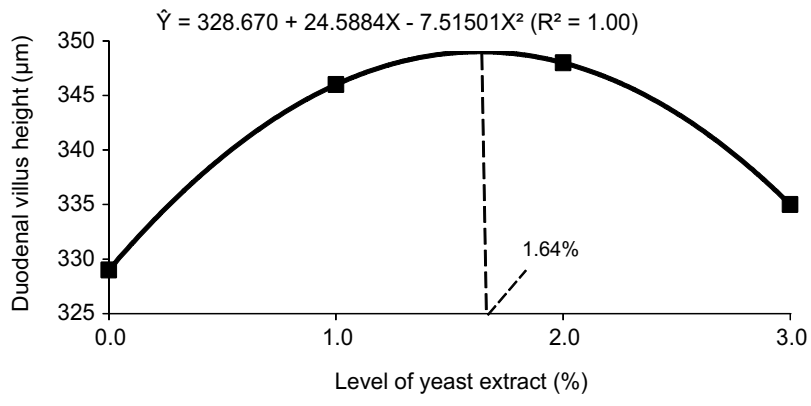

Figure 3 - Effect of yeast extract levels on duodenal villus height.



Figure 4 - Effect of yeast extract on duodenal crypt depth.

Another effect of nucleotides that may have contributed to the improvement observed in the duodenal mucosa is their potential benefit on the intestinal microbiota. A study conducted by Mateo et al. (2004) demonstrated that the inclusion of nucleotides on piglet diets had a positive influence on the gastrointestinal microbiota, increasing the concentrations of Lactobacillus acidophilus and Bifidobacterium spp, and decreasing the concentration of Clostridium perfringens. According to Mourão et al. (2005), the reduction of pathogenic bacteria in the gut can enhance intestinal mobility by increasing the proliferation of epithelial cells and, consequently, intestinal villus height.

Yeast extract levels had no effect $(\mathrm{P}>0.10)$ on villus height, crypt depth or jejunal villus:crypt ratio. These results support the findings of Andrés-Elias et al. (2007), who found no effect of the inclusion of nucleotides in piglet diets on morphometric variables assessed at the jejunum.

Although the benefits of yeast extract on the intestinal mucosa were restricted to the duodenum, they were enough to improve the growth rate of the piglets.

No difference $(\mathrm{P}>0.10)$ was found in the morphometric parameters evaluated at the duodenum and jejunum of the piglets when the control diet containing $4.0 \%$ plasma was compared with diets containing $2.0 \%$ plasma and different levels of yeast extract.

The presence of antibacterial agents in the composition of the diets used in this study could reduce the antigen load to which the mucosa was exposed, contributing to limit the benefits of yeast extract on intestinal morphometry.

\section{Conclusions}

The addition of $1.91 \%$ yeast extract to the feed of piglets from 21 to 35 days of age allowed for the replacement of $50 \%$ plasma in the diet, providing higher weight gain at 35 days and improving daily feed intake. Yeast extract at 1.64 and $1.16 \%$ improves the structure of the intestinal mucosa (duodenal villus height and crypt depth, respectively).

\section{Acknowledgments}

Financial support was provided by CNPq (National Council for Scientific and Technological Development Brazil) and Alltech of Brazil.

\section{References}

ABREU, M.L.T.; DONZELE, J.L.; SARAIVA, A. et al. Glutamina, nucleotídeos e plasma suíno em rações para leitões desmamados/ Glutamine, nucleotides and swine plasma in diets for weaned piglets. Revista Brasileira de Zootecnia, v.39, p.520-525, 2010.

ANDRÉS-ELIAS, N.; PUJOLS, J.; BADIOLA, I. et al. Effect of nucleotides and carob pulp on gut health and performance of weanling piglets. Livestock Science, v.108, p.280-283, 2007.

BONTEMPO, V.; DI GIANCAMILlO, A.; SAVOINI, G. et al. Live yeast dietary supplementation acts upon intestinal morphofunctional aspects and growth in weanling piglets. Animal Feed Science Technology, v.129, p.224-236, 2006.

BUENO, J.; TORRES, M.; ALMENDROS, A. et al. Effect of dietary nucleotides on small intestinal repair alter diarrhoea. Histological and ultrastructural changes. Gut, v.35, p.926-933, 1994.

BUTS, J.P.; BERNASCONI, P.; VAERMAN, J.P. et al. Stimulation of secretory $\operatorname{IgA}$ and secretory component of immunoglobulins in small intestine of rats treated with Saccharomyces boulardii. Digestive Diseases and Sciences, v.35, p.251-256, 1990.

CARLSON, M.S.; VEUM, T L.; TURK, J.R., Effects of yeast extract versus animal plasma in weanling pig diets on growth performance and intestinal morphology. Journal of Swine Health and Production, v.13, p.204-209, 2005.

COFFEY, R.D.; CROMWELL, G.L. Use of spray-dried animal plasma in diets for weanling pigs. Pig News and Information, v.22, p.39-48, 2001.

COSTA, L.L. Plasma animal e extrato de levedura em dietas para leitões desmamados aos 21 dias de idade: desempenho e respostas fisiológicas. 2006. 86f. Dissertação (Doutorado em Zootecnia) - Universidade Federal de Lavras, Lavras.

DIEHL, J. All in good taste: creating natural savoury flavorings from yeast. Proceedings of Alltech's 20th Annual Symposium. Nutritional Biotechnology in the Feed and Food Industries. Nottingham: Nottingham University Press, 2004. p.258-263.

KLINDT, J. Influence of litter size and creep feeding on preweaning gain and influence of preweaning growth on growth to slaughter in barrows. Journal of Animal Science, v.81, p.2434-2439, 2003. 
LAWRENCE, K.R.; GOODBAND, R.D.; TOKACH, M.D.S. et al. Comparison of wheat gluten and spray-dried animal plasma in diets for nursery pigs. Journal of Animal Science, v.82, p.3635-3645, 2004.

LEHNINGER, A.L.; NELSON, D.L.; COX, M.M. Princípios da bioquímica. 3.ed. São Paulo: Sarvier, 2002. 978p.

LELEIKO, N.S.; BRONSTEIN, A.D.; BALIGA, B.S. et al. De novo purine nucleotide synthesis in the rat small and large intestine: effect of dietary protein and purines. Journal of Pediatric Gastroenterology and Nutrition, v.2, p.313-319, 1983.

MARIBO, H.; SPRING, P. Yeast extract as a protein source for weanling piglet. In: SYMPOSIUM ON VITAMINS AND ADDITIVES IN NUTRITION OF MAN AND ANIMALS, 9., 2003, Jema/Thurinigia, Germany. Proceedings... Jema/Thurinigia, 2003. (CD-ROM).

MARTINEZ-PUIG, D.; MANZANILLA, E.G.; MORALES, J. et al. Dietary nucleotide supplementation reduces occurrence of diarrhoea in early weaned pigs. Livestock Science, v.108, p.276-279, 2007

MATEO, C.D.; DAVE, R.; STEIN, H.H. Effects os suplemental nucleosides for newly weaned pigs. Journal of Animal Science, v.82, p.71, suppl. 2, 2004. (Abstr.)

MATEO, C.D.; STEIN, H.H. Nucleotides and young animal health: can we enhance intestinal tract development and immune funcion? Nutritional biotechnology in the feed and food industries. Nottingham: Nottingham University Press, 2004. p. 159-170.

MOORE, K.L.; MULLAN, B.P.; PLUSKE, J.R. et al. The use of nucleotides, vitamins and functional amino acids to enhance the structure of the small intestine and circulating measures of immune function in the post-weaned piglet. Animal Feed Science and Technology, v.165, p.184-190, 2011.

MOURÃO, J.L.; PINHEIRO, V.; ALVES, A. et al. Effect of mannan oligosaccharides on the performance, intestinal morphology and cecal fermentation of fattening rabbits. Animal Feed Science and Technology, v.126, p.107-120, 2005.

RIGUEIRA, L.C.M. Plasma e ou extrato de levedura em dietas de leitões nos períodos pré e pós-desmame. 2009. $59 \mathrm{f}$. Tese (Doutorado em Zootecnia) - Faculdade de Ciências Agrárias e Veterinárias/Universidade Estadual Paulista Júlio de Mesquita Filho, Jaboticabal.

ROSTAGnO, H.S.; ALBINO, L.F.T.; DONZELE, J.L. et al. Tabelas Brasileiras para aves e suínos: composição de alimentos e exigências nutricionais. Viçosa, MG: UFV, 2005. 186p.

SAMPAIO, I.B.M. Estatística aplicada à experimentação animal. Belo Horizonte: FEPMVZ, 1998. 221p.

SAUER, N.; MOSENTHIN, R.; BAUER, E. The role of dietary nucleotides in single-stomach animals. Nutrition Research Reviews, 2011, v.13, p.1-14, 2011

SHEN, Y.B.; PIAO, X.S.; KIN, S.W. Effects of yeast culture supplementation on growth performance, intestinal health, and immune response of nursery pigs. Journal of Animal Science, v.87, p.2614-2624, 2009.

TIBBETTS, G.W. Nucleotides from yeast extract: potential to replace animal protein sources in food animal diets. In: ANNUAL SYMPOSIUM OF NUTRITIONAL BIOTECHNOLOGY IN THE FEED AND FOOD INDUSTRIES, 18., 2002, Nottinghan. Proceedings... Nottinghan: University Press, 2002. p.435-443.

VAN DER PEET-SCHWERING, C.M.C.; JANSMAN, A.J.M.; SMIDT, H. et al. Effects of yeast culture on performance, gut integrity and blood cell composition of weanling pigs. Journal of Animal Science, v.85, p.3099-3109, 2007.

VAN HEUGTEN, E.; FUNDERBURKE, D.W.; DORTON, K.L. Growth performance, nutrient digestibility, and fecal microflora in weanling pigs fed live yeast. Journal of Animal Science, v.81, p.1004-1012, 2003.

YU, I.T.; WU, G.F.; YANG, P.C. Rôles of glutamine and nucleotides in combination in growth, immune responses FMD antibody titres of weaned pigs. Animal Science, v.75, p.379-385, 2002. 